\title{
A review of mesenchymal stem cell injections for osteoarthritis
}

\author{
Charles Giangarra, MD'1, Jill Goodwin, MD², Franklin D. Shuler, MD', \\ Timothy Wilson-Byrne, MD', John J. Jasko, MD'1
}

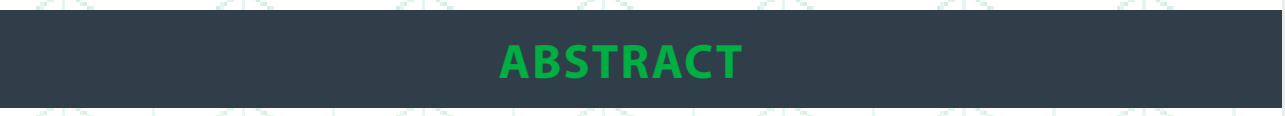

Mesenchymal stem cell (MSC) injections for osteoarthritis is reviewed.

Methods: PubMed search was conducted to identify articles in English from 20032018 that used intra- articular injection (IA), cartilage repair, cartilage regeneration, chondral injury, adipose stem cells, bone marrow stem cells, mesenchymal stem cells, or autologous stem cells.

RESULTS: 388 patients receiving IA MSC injections are discussed with data obtained from 10 case reports or case series, 4 randomized clinical trials (RCT), 1 cohort study, and 3 case controlled therapeutic studies.

ConCLUSIONS: MSC injections may be an effective adjunct in the management of osteoarthritis and a variety of cartilage related pathologies.
Author affiliations are listed at the end of this article.

Correspondence to: Jill Goodwin, MD University of Arizona College of Medicine Phoenix jill.goodwin@bannerhealth.com

\section{KEYWORDS}

stem cells, osteoarthritis, review

\section{INTRODUCTION}

Osteoarthritis (OA) is a degenerative disease of diarthrodial joints characterized by loss of articular cartilage, deformity, and pain. The two greatest risk factors for $O A$ are obesity and joint injury. ${ }^{1,2}$ Symptomatic OA is reported in $12 \%$ of American adults, with as many as $37 \%$ of adults demonstrating radiographic evidence of $\mathrm{OA} .{ }^{3} \mathrm{OA}$ is a growing problem due to aging population, obesity epidemic, and low intrinsic capacity for cartilage damage repair. Mesenchymal stem cells (MSCs) can present a novel paradigm to deal with the problem of tissue regeneration, cartilage damage, and OA. Their paracrine effect on surrounding tissue reduces inflammatory responses with MSCs providing regenerative cells to repair damaged cartilage. ${ }^{4}$ The goal of this article is to provide a review of the use of MSCs delivered directly to diarthrodial joints by intraarticular injections for orthopedic cartilage repair and symptom relief.
Numerous non-pharmacologic and pharmacologic options are used for symptom management in $\mathrm{OA}$, but none of these strategies can improve the structural damage that occurs with OA.,6 Current OA treatment recommendations by the American Association of Orthopedic Surgeons (AAOS) emphasize educational and physical therapy, the use of acetaminophen and NSAID drugs, and intra-articular corticosteroid injections. ${ }^{7}$ Their recommendations regarding the use of growth factor injections and/or platelet rich plasma (PRP) remain inconclusive. ${ }^{7}$

Surgical management of OA involves different degrees of invasive procedures with total joint replacement being the most common and the most invasive. Less invasive methods such as autologous chondrocyte implantation ( $\mathrm{ACl}$ ) have data proven benefit but an inability to correct large osteochondral defects. ${ }^{8}$ Microfracture and arthroscopic debridement of tissue also offer symptomatic benefit with success 
rates similar to other less invasive techniques like autologous matrix induced chondrogenesis (AMIC); however, microfracture and arthroscopic debridement may result in the formation of biomechanically inferior fibrocartilage. ${ }^{9}$ One main goal of newer treatment of OA is the delivery or induction of stem cells to produce true hyaline cartilage.

The success seen using mesenchymal stem cell therapy is rooted in the ability of MSCs to differentiate into all mesodermal tissues, specifically cartilage, bone, ligament, and tendon. They are also capable of modulating functions of $T$ and $B$ cells and secreting a variety of growth factors and cytokines like IL-10 and IL-12p40, which are anti-inflammatory in function. ${ }^{10-12}$ This paracrine mechanism is thought to be a major directing force to accelerate and direct tissue repair by host derived cells. ${ }^{13}$ MSCs are thought to suppress local immune response by producing cytokines and prostaglandin E2, inhibiting fibrosis, and further stimulating differentiation of stem cells. ${ }^{14,15}$ MSCs have also demonstrated homing ability, specifically incorporating into injured tissue and assisting the healing of native tissues. ${ }^{16}$ Preclinical evidence has shown that MSCs injected into animal models of naturally occurring $O A$, enzyme-induced $O A$, and post-traumatic OA may help to regenerate cartilage lesions. $1^{7,18}$ The research using animal models and comparisons of scaffold vs non-scaffold stem cell application has also been well reviewed and detailed previously. ${ }^{17,19-21}$ These features make MSCs an attractive strategy for OA management with MSC isolation and delivery being critical to clinical success.

Traditionally, MSCs have been isolated from bone marrow, typically from the iliac crest. ${ }^{22}$ Wakitani et al. were the first to demonstrate the regenerative use of MSCs for articular cartilage repair in humans by surgically implanting culture-expanded bone marrow MSCs. ${ }^{23}$ Bone marrow- mesenchymal stem cells (BM-MSCs) have been widely studied but carry the morbidity associated with donor site pain and infection. However, in the past decade, multiple sources including adipose tissue, synovium, periosteum, umbilical cord blood, and peripheral blood have also been studied. Key components in selection of an appropriate MSC source include the accessibility of the harvest tissue, stem cell population density, and ease of cell differentiation, making adipose-derived stem cells (ADSCs) very attractive. ${ }^{24-26}$ ADSCs have been demonstrated to have similar differentiation capacity and morphology to bone marrow derived cells. ${ }^{24}$ Although the most chondrogenic and osteogenic source of MSCs is synovium, ADSCs have chondrogenic and osteogenic activity requiring minimal stimulation by growth factors and cytokines. ${ }^{27-29}$ Augmentation, especially with a co-injection of PRP, may be beneficial. ${ }^{30}$

PRP is novel biologic scaffold that has been widely used as a MSC carrier. PRP is non- immunogenic, readily bio-absorbable, and easily prepared in a perioperative setting, and thus meets the major criteria as a MSC carrier. ${ }^{30} \mathrm{~A}$ double blind prospective multi-center trial by Mishra et al. in 2013 demonstrated clinically meaningful improvement in refractory tennis elbow treated with PRP. ${ }^{31}$

\section{BONE MARROW CULTURE EXPANDED MESENCHYMAL STEM CELLS}

Bone marrow mesenchymal stem cells (BMMSCs) are the best characterized MSCs and have osteogenic and chondrogenic potential that is greater than that of ADSCs. ${ }^{27}$ These MSCs are a reliable source for intra-articular injections and have not been shown to increase risk of malignancy. ${ }^{32}$ The earliest reports of successful BM-MSC injection therapy came in 2006 when Centeno et al. described a case report of a male patient with a twenty year history of hip pain and a diagnosis of OA. The patient was treated with two intra-articular hip injections of augmented BM-MSC one month apart. BM-MSC concentrate was added to hyaluronic acid and a thrombin activated platelet scaffold. The first injection was estimated to contain $<100,000$ BM-MSC and the second 300-400,000 BM-MSC. At the time of the second injection, the patient had no MRI evidence of improvement but reported clinical improvement. At eight weeks post-injection, evidence of increased joint space and neocortex formation over the area of previous subchondral cysts was reported. Walking distances and sitting tolerances improved two levels as compared with pre-injection scores. ${ }^{33}$ Additional case reports and case studies have been reported (Table 1). 


\begin{tabular}{|c|c|c|c|c|c|c|c|c|}
\hline $\begin{array}{l}\text { Author/ } \\
\text { Journal }\end{array}$ & $\begin{array}{l}\text { Study } \\
\text { Type }\end{array}$ & Outcomes & Pathology & Treatment & $\begin{array}{l}\text { Additional } \\
\text { Treatment }\end{array}$ & $\begin{array}{l}\# \\
\text { Patient } \\
\mathrm{s}\end{array}$ & $\begin{array}{l}\text { Follow } \\
\text {-Up }\end{array}$ & $\begin{array}{l}\text { Significant } \\
\text { Results }\end{array}$ \\
\hline $\begin{array}{l}\text { Centeno et } \\
\text { al. } 2006 \\
\text { Pain } \\
\text { Physician }\end{array}$ & $\begin{array}{l}\text { Case } \\
\text { report }\end{array}$ & $\begin{array}{l}\text { Harris } \\
\text { Hip Score }\end{array}$ & Hip OA & $\begin{array}{l}\text { Two } \\
\text { injections } \\
\text { of BMSC: } \\
1-3 \times 10^{5} \\
\text { cells }\end{array}$ & $\begin{array}{l}\text { HA and } \\
\text { thrombin - } \\
\text { activated } \\
\text { platelet } \\
\text { scaffold }\end{array}$ & 1 & $\begin{array}{l}4 \& 8 \\
\text { weeks }\end{array}$ & $\begin{array}{l}\text { MRI showed new } \\
\text { neo-cortex at } 8 \\
\text { weeks }\end{array}$ \\
\hline $\begin{array}{l}\text { Centeno et } \\
\text { al. } 2008 \\
\text { Pain } \\
\text { Physician }\end{array}$ & $\begin{array}{l}\text { Case } \\
\text { report }\end{array}$ & $\begin{array}{l}\text { VAS } \\
\text { functional } \\
\text { rating } \\
\text { index }\end{array}$ & Knee OA & $\begin{array}{l}\text { Cultured } \\
\text { BMSC: } \\
22.5 \times 10^{5} \\
\text { cells }\end{array}$ & $\begin{array}{l}\text { Platelet } \\
\text { lysate } \\
\text { injections }\end{array}$ & 1 & $\begin{array}{l}24 \\
\text { weeks }\end{array}$ & $\begin{array}{l}\text { Decreased VAS, } \\
\text { and increased } \\
\text { cartilage \& } \\
\text { meniscus volume } \\
\text { on MRI at } 3 \\
\text { months }\end{array}$ \\
\hline $\begin{array}{l}\text { Emadedin } \\
\text { et al. } 2012 \\
\text { Arch Iran } \\
\text { Med }\end{array}$ & $\begin{array}{l}\text { Case } \\
\text { series }\end{array}$ & $\begin{array}{l}\text { VAS, } \\
\text { WOMAC, } \\
\text { walking } \\
\text { distance }\end{array}$ & Knee OA & $\begin{array}{l}\text { Cultured } \\
\text { BMSC: } \\
24 \times 10^{8} \\
\text { cells }\end{array}$ & & 6 & 1 year & $\begin{array}{l}\text { MRI with } \\
\text { cartilage } \\
\text { thickening at } 6 \\
\text { months }\end{array}$ \\
\hline $\begin{array}{l}\text { Orozco et } \\
\text { al. } 2013 \\
\text { Transplant } \\
\text {-ation }\end{array}$ & $\begin{array}{l}\text { Case } \\
\text { series }\end{array}$ & $\begin{array}{l}\text { VAS, } \\
\text { WOMAC }\end{array}$ & $\begin{array}{l}\text { Knee: } \\
\text { Kellgren } \\
\& \\
\text { Lawrence } \\
\text { Grade } 3,4\end{array}$ & $\begin{array}{l}\text { Cultured } \\
\text { BMSC: } \\
\sim 40 \times 10^{8} \\
\text { injected }\end{array}$ & & 12 & 1 year & $\begin{array}{l}\text { Significant } \\
\text { improvement in } \\
\text { VAS scores }\end{array}$ \\
\hline $\begin{array}{l}\text { Lee et al. } \\
2012 \\
\text { Ann Acad } \\
\text { Med } \\
\text { Singapore }\end{array}$ & $\begin{array}{l}\text { Case } \\
\text { series }\end{array}$ & $\begin{array}{l}\text { ICRS } \\
\text { evaluation } \\
\text { package, } \\
\text { MRI }\end{array}$ & $\begin{array}{l}\text { Knee: full } \\
\text { thickness } \\
\text { cartilage } \\
\text { lesions }\end{array}$ & $\begin{array}{l}\text { Injected } \\
\text { vs. open- } \\
\text { implanted }\end{array}$ & $\begin{array}{l}\text { HA } \\
\text { injection at } \\
\text { weeks } 2,4\end{array}$ & $\begin{array}{l}35 \\
\text { injecte } \\
\mathrm{d} \\
35 \\
\text { open }\end{array}$ & $\begin{array}{l}24 \\
\text { months }\end{array}$ & $\begin{array}{l}\text { Improvement in } \\
\text { IKDC, Lysholm, } \\
\text { VAS, and SF36 in } \\
\text { all treatment } \\
\text { groups }\end{array}$ \\
\hline $\begin{array}{l}\text { Davatchi } \\
\text { et al. } 2011 \\
\text { Int J } \\
\text { Rheum } \\
\text { Dis }\end{array}$ & $\begin{array}{l}\text { Case } \\
\text { series }\end{array}$ & $\begin{array}{l}\text { Walking } \\
\text { time, } \\
\text { VAS }\end{array}$ & Knee OA & $\begin{array}{l}\text { Cultured } \\
\text { BMSC: } \\
8 \times 10^{7} \\
\text { injected }\end{array}$ & & 4 & $\begin{array}{l}6 \\
\text { months }\end{array}$ & $\begin{array}{l}\text { Increased walking } \\
\text { time, } \\
\text { improvement in } \\
\text { VAS }\end{array}$ \\
\hline $\begin{array}{l}\text { Varam et } \\
\text { al. } 2013 \\
\text { J Indian } \\
\text { Med } \\
\text { Assoc }\end{array}$ & RCT & $\begin{array}{l}\text { ADL } \\
\text { evaluation } \\
\text {, OA } \\
\text { outcomes } \\
\text { score, } \\
\text { VAS } \\
\end{array}$ & Knee OA & $\begin{array}{l}\text { BMSC } \\
\text { injections } \\
\text { following } \\
\text { debrideme } \\
\text { nt }\end{array}$ & & $\begin{array}{l}25 \text { in } \\
\text { each } \\
\text { group }\end{array}$ & $\begin{array}{l}6 \\
\text { months }\end{array}$ & $\begin{array}{l}\text { Improved OAOS } \\
\text { and VAS }\end{array}$ \\
\hline $\begin{array}{l}\text { Wong et } \\
\text { al. } 2013 \\
\text { Arthrosco } \\
\text { py }\end{array}$ & RCT & $\begin{array}{l}\text { MOCAR } \\
\text { T, } \\
\text { Lysholm, } \\
\text { Tegner, } \\
\text { IKDC }\end{array}$ & Knee OA & BM-MSC & $\begin{array}{l}\text { Micro- } \\
\text { fracture, } \\
\text { high tibial } \\
\text { osteotomy }\end{array}$ & $\begin{array}{l}28 \text { in } \\
\text { each } \\
\text { group }\end{array}$ & 1 year & $\begin{array}{l}\text { Improved } \\
\text { MOCART, } \\
\text { Lysholm, Tegner, } \\
\text { and IKDC }\end{array}$ \\
\hline $\begin{array}{l}\text { Vangsness } \\
\text { et al. } 2014 \\
\text { JBJS }\end{array}$ & RCT & $\begin{array}{l}\text { MRI } \\
\text { findings, } \\
\text { VAS }\end{array}$ & Knee OA & BM-MSC & $\begin{array}{l}\text { Medial } \\
\text { meniscecto } \\
\text { my }\end{array}$ & $\begin{array}{l}55 \\
\text { patients } \\
\text { in each } \\
\text { group }\end{array}$ & $\begin{array}{l}1 \text { and } 2 \\
\text { years }\end{array}$ & $\begin{array}{l}\text { Improved } \\
\text { meniscal volume, } \\
\text { improved VAS }\end{array}$ \\
\hline
\end{tabular}

TABLE 1. Bone Marrow-Derived Mesenchymal Stem Cells (BM-MSCs)

BMSC- Bone Marrow-Derived Stem Cells; OA- osteoarthritis; HA- hyaluronic acid; WOMAC- Western Ontario and McMaster University Osteoarthritis Index; ICRS- International Cartilage Repair Society; ADL- Activities of Daily Living; VAS- Visual Analog Scale; SF-36- Short Form Health Survey; MOCART- Magnetic Resonance Observation of Cartilage Repair Tissue 
In 2008, Centeno et al. published a case of knee OA treated with a single injection of cultured BM-MSCs (22.4 million) and a platelet lysate preparation. The patient had follow-up injections of platelet lysate one and two weeks after the first injection. Excellent outcomes were reported with a decrease in visual analog score (VAS) by $95 \%$ and magnetic resonance imaging (MRI) evidence of increased cartilage volume at three months post injection. ${ }^{34}$ In 2011, a study by Davatchi et al. reported the results of four patients with knee OA who were injected with $8 \times 10^{6}$ BM-MSCs and were evaluated one week after the injection and then monthly for one year. ${ }^{35}$ Functional assessments were made by walking time to pain, stair climb number, and VAS. Three of the four subjects reported an improvement in walking time and stair climb capacity, and a $24-50 \%$ improvement in VAS. No improvement was seen on $x$-ray at followup. In another study by Emadenin et al., 6 patients with knee OA were injected with 24 million cultured BM-MSCs with 12- month follow-up. Optimal results were seen at 6 months as evaluated by VAS, Western Ontario and McMaster University Osteoarthritis Index (WOMAC), and walking distances. Importantly, pain reduction and improvement in joint function were also noted but decreased at one year. Three of the six demonstrated increased thickening of the meniscus on MRI at six months follow-up. ${ }^{36}$

In 2012, a study by Lee et al. examined the effects of injecting BM-MSCs for seventy nonrandomized patients less than 55 years of age with full thickness chondral lesions in a single compartment of the knee. Thirty-five patients received previously established treatment using arthroscopic microfracture and arthroscopic surgical implantation of MSC with periosteal flap coverage. The other thirty-five received the same arthroscopic microfracture followed by injection of 10 million BM-MSCs then $2 \mathrm{ml}$ hyaluronic acid (HA) in an outpatient clinic after surgery. Followup injections of HA ( $2 \mathrm{ml})$ at two and four weeks were also administered. Subjects were followed for twenty-four months and evaluated using International Cartilage Repair Society (ICRS) injury evaluation package, Short Form Health Survey (SF36), International Knee Documentation Committee (IKDC) subjective evaluation form, the Lysholm knee scale, and the Tegner activity level scale. A post-op MRI was also obtained. MRI results at one year showed neocartilage with good filling and significant reduction in underlying marrow edema. Improvement was seen in all patients, but the injected group was reported to have superior results according to the IKDC and Lysholm scores. No difference was noted between the VAS and the SF-36 score between the groups. As a result of the excellent clinical outcomes, no second look arthroscopies were performed. ${ }^{37}$

Varma et al. conducted a randomized controlled trial (RCT) utilizing BM-MSC with fifty patients with mild to moderate knee OA. Half were treated by injection of buffy coated BM-MSC concentrate following arthroscopic debridement and compared to debridement alone. VAS and osteoarthritis outcome scores (OAOS) were evaluated at one, two, three, and six months follow-up. Significant improvement was seen at six months for the stem cell group in VAS (5.24 vs 2.12 ) and OAOS scores (56.57 vs 79.28). ${ }^{38}$ Wong et al. also conducted an RCT using BM-MSC injections at the time of microfracture and high tibial osteotomy (HTO) for twenty-eight patients, and compared these results to twenty-eight patients randomized to receive no MSC injection..$^{39}$ At one year follow-up, patients' magnetic resonance observation of cartilage repair tissue (MOCART) scores were improved in the group receiving MSCs. Patients in this group also reported statistically significant improvement in Lysholm, Tegner, and IKDC scores.

In 2013, a cohort of twelve patients with Kellgren and Lawrence grade II-IV knee OA was injected with 40 million cultured BM-MSCs and followed for twelve months. Evaluation by MRI T2 showed improvement in cartilage, as well as significant clinical improvement in functional scores and VAS. ${ }^{40}$ These studies clearly demonstrate that optimal dosing of MSC is not known with ranges from 100,000 to 40 million BM-MSCs used in the studies presented. In 2014, Vangsness et al. published their results from an RCT using BM-MSCs versus placebo injections administered to fifty-five patients seven to ten days after a partial medial meniscectomy. ${ }^{41}$ Patients received injections of either 50×106 allogeneic BMMSCs, $150 \times 106$ MSCs, or a hyaluronic acid control. The authors found increased meniscal volume on MRI in both groups receiving MSCs, and significantly increased VAS score improvement at one and two 
years in the MSC groups compared to the control group.

\section{ADIPOSE-DERIVED MESENCHYMAL STEM CELLS (ADSCS)}

A critical difference in studies using ADSCs versus BM-MSCs is the near immediate injection of stem cells following harvest; readily available reservoirs include the buttock, abdominal, and infrapatellar fat pads. ${ }^{26,30,42-45}$ Thus, adipose tissue is ideal for same day harvest and injection, making it attractive for traumatic injury cases. Recent studies using ADSCs have covered a wider spectrum of chondral related pathologies, including OA of the hip and knee, osteonecrosis of the femoral head, and osteochondral lesions of the talus (Table 2).

A case series published by Pak et al. in 2011 evaluated the safety and efficacy of concentrated ADSCs in four patients. ${ }^{43}$ Two patients had stage IV osteonecrosis of the femoral head and were given intra-articular injections of ADSC concentrate mixed with $\mathrm{PRP}, \mathrm{HA}$, and $\mathrm{CaCl}_{2}$. Subjects returned every week for follow-up injection of PRP and $\mathrm{CaCl}_{2}$ for a total of four injections. Two other subjects with OA of the knee were injected with ADSC, PRP, and $\mathrm{CaCl}_{2}$. They also had weekly injections of PRP and low dose dexamethasone for four weeks. Patients were seen in follow-up at three weeks and twelve weeks. Pre-procedure evaluations included VAS, MRI, and functional rating index. Repeat MRI at twelve weeks showed bone regeneration of the femoral heads and regeneration of the meniscus in the OA patients. This study suggests that ADSCs may be partially responsible for patients' improvement. In 2013, the same group published another case series using ADSC intra-articular injections to treat chondromalacia patellae in three patients. ${ }^{42}$ Each was evaluated pre-procedurally with MRI and VAS pain assessment. Low abdominal liposuction was used to collect ADSC and cells were concentrated the same day as injection. Sixteen million concentrated ADSCs were injected into the retropatellar joint space with PRP and HA. All patients returned on day three, seven, fourteen, and twenty-eight for repeat injections of PRP and HA with the day fourteen injection including low dose dexamethasone. Patients were seen for follow-up at three months, when MRI demonstrated cartilage-like tissue regeneration, and subjects reported $80-90 \%$ pain improvement. However, it should be noted that despite these positive outcomes, there were discrepancies in the authors' reported protocol that limit interpretation of this study.

In 2012, Koh et al. published a therapeutic case series of twenty-five subjects to evaluate whether percutaneous injection of ADSCs from the infrapatellar fat pad could improve clinical outcomes for knee OA. ${ }^{30}$ Intra-articular injections of ADSCs (mean 1.9 million) in concert with PRP and arthroscopic debridement were compared to a matched control group without injections of stem cells. All patients had follow-up injections of PRP on day seven and fourteen. Pre- and post- operative evaluations were performed using VAS, Lysholm, and Tegner scores, and all revealed greater total improvement when compared to the control group. Overall outcomes were similar for pain relief and functional improvement. Patients in this study were further evaluated at two years by MRI, VAS, and scores for WOMAC and WORMS. Interestingly, an improvement of WOMAC scores, from 49.9 at 0-1 years to 30.3 at 1-2 years was observed. Possibly the most important finding from the group was the correlation between cell count at injection and patient outcomes. Notably, there was also a positive correlation between the dosage of ADSCs and improvement of pain, function, and MRI findings. ${ }^{44}$

Another study assessing the effect of ADSCs included thirty study patients and thirty-five control patients with osteochondral (OCD) lesions of the talus. All patients were over fifty years of age. This study assessed the role of ADSCs in treating talar OCD lesions in conjunction with marrow stimulation vs. marrow stimulation alone. ADSCs were harvested from the butt pad the day prior to treatment. Outcomes were assessed using VAS, AOFAS score, Roles and Maudsley score, and Tegner activity scale over a mean of twenty-two months. Patient outcome scores improved in both groups, and the authors noted that patients with lesions larger than 109 $\mathrm{mm} 2$ or with subchondral cysts were likely to have superior outcomes when treated with ADSCs. ${ }^{45}$

Recently, Spasovski et al. evaluated the clinical and radiographic outcomes of a single injection 


\begin{tabular}{|c|c|c|c|c|c|c|c|c|}
\hline $\begin{array}{l}\text { Author// } \\
\text { Journal }\end{array}$ & $\begin{array}{l}\text { Study } \\
\text { Type }\end{array}$ & Outcomes & Pathology & Treatment & $\begin{array}{l}\text { Additiona } \\
1 \\
\text { Treatmen } \\
t\end{array}$ & $\begin{array}{l}\# \\
\text { Patients }\end{array}$ & $\begin{array}{l}\text { Follow } \\
\text {-Up }\end{array}$ & Significant Results \\
\hline $\begin{array}{l}\text { Pak et al. } \\
2013 \\
\text { PLOS } \\
\text { ONE }\end{array}$ & $\begin{array}{l}\text { Case } \\
\text { series }\end{array}$ & $\begin{array}{l}\text { Pain scale/ } \\
\text { MRI } \\
\text { evaluation }\end{array}$ & $\begin{array}{l}\text { Chondro- } \\
\text { malacia }\end{array}$ & $\begin{array}{l}\text { Concentrat } \\
\text { ed } \\
\text { ADSCs: } \\
\sim 16 \times 106\end{array}$ & HA, PRP & 3 & $\begin{array}{l}18 \\
\text { months }\end{array}$ & $\begin{array}{l}\text { Improvement in } \\
\text { subjective pain } \\
\text { scores, and MRI } \\
\text { with evidence of } \\
\text { cartilage restoration }\end{array}$ \\
\hline $\begin{array}{l}\text { Pak et al. } \\
2011 \mathrm{~J} \\
\text { Med Case } \\
\text { Reports }\end{array}$ & $\begin{array}{l}\text { Case } \\
\text { series }\end{array}$ & $\begin{array}{l}\text { MRI, } \\
\text { VAS, } \\
\text { functional } \\
\text { rating } \\
\text { index }\end{array}$ & $\begin{array}{l}\text { Hip } \\
\text { osteo- } \\
\text { necrosis } \\
\text { and knee } \\
\text { OA }\end{array}$ & $\begin{array}{l}\text { Concentrat } \\
\text { ed ADSCs }\end{array}$ & $\begin{array}{l}\text { PRP, HA, } \\
\mathrm{CaCl} 2\end{array}$ & 4 & $\begin{array}{l}12 \\
\text { weeks }\end{array}$ & $\begin{array}{l}\text { MRI with evidence } \\
\text { of increased cartilage } \\
\text { thickness }\end{array}$ \\
\hline \begin{tabular}{l|} 
Koh et al. \\
2012 \\
Knee
\end{tabular} & $\begin{array}{l}\text { Case } \\
\text { Contr } \\
\text { ol }\end{array}$ & $\begin{array}{l}\text { Lysholm } \\
\text { score, } \\
\text { Tegner, } \\
\text { VAS }\end{array}$ & Knee OA & $\begin{array}{l}\text { Concentrat } \\
\text { ed ADSCs }\end{array}$ & $\begin{array}{l}\text { PRP, } \\
\text { arthro- } \\
\text { scopic } \\
\text { debride- } \\
\text { ment }\end{array}$ & $\begin{array}{l}25 \\
\text { cases in } \\
\text { each } \\
\text { group }\end{array}$ & $\begin{array}{l}12 \\
\text { months }\end{array}$ & $\begin{array}{l}\text { No difference from } \\
\text { control }\end{array}$ \\
\hline $\begin{array}{l}\text { Koh et al. } \\
2013 \\
\text { Arthro- } \\
\text { scopy }\end{array}$ & $\begin{array}{l}\text { Case } \\
\text { Contr } \\
\text { ol }\end{array}$ & $\begin{array}{l}\text { MRI, } \\
\text { VAS, } \\
\text { WOMAC }\end{array}$ & Knee OA & $\begin{array}{l}\text { Concentrat } \\
\text { ed ADSCs }\end{array}$ & $\begin{array}{l}\text { Arthrosco } \\
\text { pic } \\
\text { debridem } \\
\text { ent, PRP }\end{array}$ & 18 & 2 years & $\begin{array}{l}\text { Decrease in } \\
\text { WOMAC at } 2 \text { years, } \\
\text { with improvement } \\
\text { correlation with cell } \\
\text { count injected }\end{array}$ \\
\hline \begin{tabular}{l|} 
Kim et al. \\
2013 \\
Am J \\
Sports \\
Med
\end{tabular} & $\begin{array}{l}\text { Cohor } \\
\mathrm{t} \\
\text { Study }\end{array}$ & $\begin{array}{l}\text { VAS } \\
\text { AOFAS, } \\
\text { Ankle- } \\
\text { Hindfoot } \\
\text { scale, } \\
\text { Roles \& } \\
\text { Maudsley, } \\
\text { Tegner } \\
\end{array}$ & $\begin{array}{l}\text { Osteocho } \\
\text { ndral } \\
\text { talar } \\
\text { lesion }\end{array}$ & $\begin{array}{l}\text { Concentrat } \\
\text { ed ADSCs }\end{array}$ & $\begin{array}{l}\text { Arthrosco } \\
\text { pic } \\
\text { marrow } \\
\text { stimulatio } \\
\mathrm{n}\end{array}$ & $\begin{array}{l}30 \\
\text { ADSC } \\
35 \\
\text { control }\end{array}$ & $\begin{array}{l}22 \\
\text { months }\end{array}$ & $\begin{array}{l}\text { Improved mean VAS } \\
\text { and AOFAS in } \\
\text { ADSC group. }\end{array}$ \\
\hline $\begin{array}{l}\text { Spasovsk } \\
\text { i et al. } \\
\text { J Gene } \\
\text { Med }\end{array}$ & $\begin{array}{l}\text { Case } \\
\text { series }\end{array}$ & $\begin{array}{l}\text { VAS, } \\
\text { KSS, } \\
\text { radiograph } \\
\text { s }\end{array}$ & Knee OA & $\begin{array}{l}0.5- \\
1.0 \times 10^{\gamma} \\
\text { ADSCs }\end{array}$ & & $\begin{array}{l}9 \\
\text { patients }\end{array}$ & $\begin{array}{l}18 \\
\text { months }\end{array}$ & $\begin{array}{l}\text { Improved VAS and } \\
\text { KSS }\end{array}$ \\
\hline
\end{tabular}

TABLE 2. Adipose-Derived Mesenchymal Stem Cells (ADSCs)

ADSC- Adipose-Derived Stem Cells; OA- osteoarthritis; PRP- platelet rich plasma; HA- hyaluronic acid; WOMACWestern Ontario and McMaster University Osteoarthritis Index; VAS- Visual Analog Scale; AOFAS- American Orthopaedic Foot and Ankle Society; KSS- Knee Society Score 
of ADSCs in nine patients with knee osteoarthritis. The authors used a concentration of 0.5-1.0 x 107 cells. After eighteen months of follow-up, patients reported improvement in VAS and knee society score (KSS). Radiographs showed neither improvement nor progression of degenerative changes. ${ }^{46}$

\section{PERIPHERAL BLOOD STEM CELLS}

Peripheral blood progenitor cells (PBPCs) are easily obtained with both central and peripheral intravenous access and have been successfully used to treat international cartilage repair society (ICRS) grade III-IV chondral knee lesions. The case series by Saw et al. describes five subjects who were treated with arthroscopic subchondral drilling followed by five weekly injections of PBPCs mixed with HA.47 Second look arthroscopy demonstrated articular cartilage regeneration with histologic sections showing hyaline cartilage regeneration as the major component of the repaired tissue. The success of the case series prompted Saw et. al. to evaluate the treatment process of five weekly injections of PBPCs mixed with HA in an RCT of fity patients with ICRS grade III-IV lesions randomized to either 1 ) those treated with subchondral drilling and $\mathrm{HA}$ alone, and 2) those treated with drilling followed by PBPCs and HA (Table 3). Subjective IKDC scores and MRI evaluations were made pre- and post-operatively on all patients, and second look arthroscopy and biopsy at eighteen months were taken from sixteen patients in each group. There were no statistically significant differences in IKDC scores. However, statistically significant improvement was seen in both MRI findings and ICRS II scores in the control group. Furthermore, more type 2 collagen was identified in the intervention group, as compared to "limited to no" type 2 collagen in the control. ${ }^{48}$

In another case study of five patients who failed conservative therapy for knee OA, arthroscopic micro drilling was performed in all patients with two subsequent IA injections of PBPCs with

\begin{tabular}{|l|l|l|l|l|l|l|l|}
\hline $\begin{array}{l}\text { Author/ } \\
\text { Journal }\end{array}$ & $\begin{array}{l}\text { Study } \\
\text { Type }\end{array}$ & Outcomes & $\begin{array}{l}\text { Patholog } \\
\text { y }\end{array}$ & $\begin{array}{l}\text { Additional } \\
\text { Treatment }\end{array}$ & $\begin{array}{l}\text { \# } \\
\text { Patient } \\
\text { s }\end{array}$ & $\begin{array}{l}\text { Follow- } \\
\text { Up }\end{array}$ & Significant Results \\
\hline $\begin{array}{l}\text { Saw et al. } \\
2013 \\
\text { Arthrosc } \\
\text { opy }\end{array}$ & RCT & $\begin{array}{l}\text { IKDC } \\
\text { scores, } \\
\text { MRI, } \\
\text { biopsy }\end{array}$ & $\begin{array}{l}\text { Knee } \\
\text { chondral } \\
\text { lesion }\end{array}$ & $\begin{array}{l}\text { HA, } \\
\text { subchondral } \\
\text { drilling }\end{array}$ & $\begin{array}{l}25 \text { in } \\
\text { each } \\
\text { group }\end{array}$ & $\begin{array}{l}18 \\
\text { months }\end{array}$ & $\begin{array}{l}\text { Increased amounts of } \\
\text { Type II collagen in stem } \\
\text { cell group }\end{array}$ \\
\hline $\begin{array}{l}\text { Saw et al. } \\
\text { 2011 } \\
\begin{array}{l}\text { Arthrosc } \\
\text { opy }\end{array}\end{array}$ & $\begin{array}{l}\text { Case } \\
\text { series }\end{array}$ & $\begin{array}{l}\text { Second } \\
\text { look } \\
\text { arthroscop } \\
\text { y, tissue } \\
\text { biopsy }\end{array}$ & $\begin{array}{l}\text { ICRS } \\
\text { grade 3-4 } \\
\text { knee } \\
\text { lesion }\end{array}$ & $\begin{array}{l}\text { Arthroscopic } \\
\text { subchondral } \\
\text { drilling, HA }\end{array}$ & 5 & $\begin{array}{l}10-26 \\
\text { months }\end{array}$ & $\begin{array}{l}\text { Biopsy evidence of } \\
\text { hyaline cartilage } \\
\text { formation }\end{array}$ \\
\hline $\begin{array}{l}\text { Turajane } \\
\text { et al } \\
\text { 2013. } \\
\text { J Med } \\
\text { Assoc } \\
\text { Thai }\end{array}$ & $\begin{array}{l}\text { Case } \\
\text { series }\end{array}$ & $\begin{array}{l}\text { WOMAC, } \\
\text { KOO, } \\
\text { biopsy }\end{array}$ & Knee OA & $\begin{array}{l}\text { Arthroscopic } \\
\text { subchondral } \\
\text { drilling, HA, } \\
\text { growth factor }\end{array}$ & 5 & 6 months & $\begin{array}{l}\text { Biopsy with increased } \\
\text { proteoglycans and } \\
\text { glycosaminoglycans } \\
\text { suggestive of hyaline } \\
\text { cartilage }\end{array}$ \\
\hline
\end{tabular}

TABLE 3. Peripheral Blood Mesenchymal Stem Cells (PBSCs)

PBSC-Peripheral blood stem cells; ; OA- osteoarthritis; HA- hyaluronic acid; WOMAC- Western Ontario and McMaster University Osteoarthritis Index; ICRS- International Cartilage Repair Society; IKDC-International Knee Documentation Committee; KOO- Knee Injury and Osteoarthritis Outcome Scores 
growth factors and $\mathrm{HA}$, repeated at days seven and fourteen. Outcomes evaluated WOMAC and knee injury and osteoarthritis outcome scores (KOO) at baseline, one, and six months along with biopsy. Significant improvements in WOMAC and KOO scores were noted in all patients at one and six months. Biopsy showed increased proteoglycan and glycosaminoglycan content which suggested hyaline cartilage formation (Table 3)..$^{49}$ PBPCs presents a less invasive alternative to traditional BM-MSC and ADSC harvest protocols.

\section{DISCUSSION}

Review of current research involving IA injection of MSCs for various chondral-related pathologies is promising. The rising interest in cartilage regeneration is predictable considering the impact that a successful regenerative treatment would have on the field of orthopedics. However, our knowledge of the process is still in the preliminary stages. The vast majority of the publications on stem cell injection therapy are preclinical, but have shown great promise in animal models and RCTs. $8,15,17,18,21$ Studies included in this review demonstrate the diversity and limitations of current research, especially relatively short patient followup and the variability in dosing regimens and use of concomitant therapies. However, symptomatic benefit and evidence of improvement on advanced imaging were noted in many studies.

MSCs can be harvested from bone marrow, adipose tissue, synovium, peripheral blood, umbilical cord blood, muscle, skin, and periosteum; each donor has a variable capacity to produce cartilage and bone. Each of these sources also differs in the relative ease or morbidity associated with harvesting MSCs. Furthermore, the optimal number of stem cells injected is far from certain. Although the dose-dependent nature of cartilage regeneration is still unknown, there is some evidence of a dosedependent effect. ${ }^{41,42}$ Of the groups reviewed, dosing varied significantly with upwards of 40 million to as few as 100,000 cells being used, making any comparison between study outcomes difficult. The proper dose for injection therapy is a key point that needs to be clarified with future research. Finally, although outside the scope of this paper, allogeneic
BM-MSCs avoid the expensive and slow cell expansion process used in autologous harvest, but theoretically may cause host immune rejection; no adverse reactions were identified in an RCT by Vega et al. in 2015 examining 30 IA injections for knee OA. ${ }^{50}$

Cellular and biochemical factors related to chondrogenesis are other key developing areas of research. Extensive in vitro work has been done showing the growing characteristics and behavior of ADSCs in recombinant BMP-2, TGF- $\beta$, PDGF and in various biologic scaffolds like PRP. ${ }^{28,51-53} \mathrm{New}$ discoveries and better understanding of MSC processes will continue to fuel advancements in the field of chondral regeneration.

Limitations of MSCs for the treatment of OA must also be considered. Long-term safety and efficacy of these therapies has not been proven. In a review by Peeters et al. of 844 injections with a mean followup of twenty-one months, the authors concluded that applications of cultured stem cells in joints appears safe..$^{54} \mathrm{~A}$ follow-up study by Jo et al. in 2017 examined the two year outcomes of their eighteen patients with knee OA who had received AD-MSC injections, and found that the clinical outcomes for low- and medium-dose groups deteriorated one year after injections, while the high-dose group results plateaued. ${ }^{55}$ Furthermore, patients with severe OA have decreased proliferative capacity of patientderived MSCs which, in addition to the burden of their advanced degeneration and deformity, limits the utility of these therapies in many patients.56 With longer follow-up and further studies, we will continue to gather data and identify potential complications regarding MSC therapies.

\section{CONCLUSION}

MSCs have potential to be a widely used modality in the next decade. New RCTs, case reports, and cohort studies demonstrate the potential use of MSCs in a variety of cartilage-related pathologies and therapies. Larger RCTs are needed to identify optimal cell sources, required cell counts for injection, cell processing methods, and ideal supplemental ingredients such as PRP, HA, and growth factors. 


\section{AUTHOR AFFILIATIONS}

1. Marshall University Joan C. Edwards School of Medicine, Huntington, West Virginia

2. University of Arizona College of Medicine, Phoenix, Arizona

\section{REFERENCES}

1. Suri P, Morgenroth DC, Hunter DJ. Epidemiology of osteoarthritis and associated comorbidities. PM\&R: The Journal of Injury, Function and Rehabilitation. 2012;4(5 Suppl):S10-19.

2. Wiesel S, Delahay J. Essentials of Orthopedic Surgery. New York: Springer Science and Business Media; 2010.

3. Dillon CF, Rasch EK, Gu Q Hirsch R. Prevalence of knee osteoarthritis in the United States: arthritis data from the Third National Health and Nutrition Examination Survey. 2006;33(11):2271-2279.

4. Granero-Molto F, Weis JA, Longobardi L, Spagnoli A. Role of mesenchymal stem cells in regenerative medicine: application to bone and cartilage repair. Expert Opinion on Biological Therapy. 2008;8(3):255-268.

5. Bobacz K. Pharmacologic treatment of hand, knee- and hip-osteoarthritis. Wien Med Wochenschr. 2013;163(9-10):236-242.

6. Hochberg MC, Altman RD et al. American College of Rheumatology 2012 Recommendations for the Use of nonpharmacologic and pharmacologic therapies in osteoarthritis of the hand, hip, and knee. Arthritis Care Res (Hoboken). 2012;64(4):465-474.

7. Jevsevar DS. Treatment of osteoarthritis of the knee: evidence-based guideline, 2nd edition. Journal of the American Academy of Orthopaedic Surgeons. 2013;21(9):571-576.

8. Steinert A. biological obstacles for persistent cellbased regeneration of articular cartilage. Arthritis Res Ther. 2007;9(3):213.

9. Anders $\mathrm{S}$ et al. A randomized controlled trial comparing autologous matrix-induced chondrogenesis (AMIC(R)) to microfracture: analysis of 1- and 2-year follow-up data of 2 centers. Open Orthop J. 2013; 7:133-143.

10. Abumaree $M$, Al Jumah $M$, Pace RA, Kalionis B. Immunosuppressive properties of mesenchymal stem cells. Stem Cell Rev Rep. 2012;8(2):375-392.
11. Nemeth $\mathrm{K}$, et al. Bone marrow stromal cells attenuate sepsis via prostaglandin $\mathrm{E}(2)$ dependent reprogramming of host macrophages to increase their interleukin-10 production. Nature Medicine. 2009;15(1):42-49.

12. Maggini J, et al. Mouse bone marrow-derived mesenchymal stromal cells turn activated macrophages into a regulatory-like profile. PLoS One. 2010;5(2):e9252.

13. Caplan AI Dennis JE. Mesenchymal stem cells as trophic mediators. Journal of Cellular Biochemistry. 2006;98(5):1076-1084.

14. Manferdini C. Adipose-derived mesenchymal stem cells exert antiinflammatory effects on chondrocytes and synoviocytes from osteoarthritis patients through prostaglandin E2. Arthritis Rheum. 2013; 65(5):1271-1281.

15. Mcllwraith C. Evaluation of intra-articular mesenchymal stem cells to augment healing of microfractured chondral defects. Arthroscopy. 2011;27(11):1552-1561.

16. Mokbel A. Homing and reparative effect of intraarticular injection of autologous mesenchymal stem cells in osteoarthritic animal model. BMC Musculoskelet Disord. 2011;12:259.

17. Vilar J. Controlled, blinded force platform analysis of the effect of intraarticular injection of autologous adipose-derived mesenchymal stem cells associated to PRGF-Endoret in osteoarthritic dogs. BMC Vet Res. 2013;9:131.

18. Toghraie F. Treatment of osteoarthritis with infrapatellar fat pad derived mesenchymal stem cells in Rabbit. Knee. 2011;18(2):71-75.

19. Gimble JM, et al. Adipose tissue as a stem cell source for musculoskeletal regeneration. Front Biosci. 2011;3:69-81.

20. Vinatier $C$, et al. Cartilage tissue engineering: towards a biomaterial-assisted mesenchymal stem cell therapy. Curr Stem Cell Res Ther. 2009;4(4):318-329.

21. Toghraie F. Scaffold-free adipose-derived stem cells (ASCs) improve experimentally induced osteoarthritis in rabbits. Arch Iran Med. 2012;15(8):495-499.

22. Jedrzejas KS M, Czekaj P. Stem cell niches exposed to tobacco smoke. Przegl Lek. 2012;69(10):1063-1073.

23. Wakitani $S$, et al. Human autologous culture expanded bone marrow mesenchymal cell transplantation for repair of cartilage defects 
in osteoarthritic knees. Osteoarthritis Cartilage. 2002;10(3):199-206.

24. Schäffler A, Büchler C. Concise review: adipose tissue-derived stromal cells-basic and clinical implications for novel cell-based therapies. Stem cells. 2007;25(4):818-827.

25. Casteilla L, Planat-Benard V, Cousin B, Silvestre JS, Laharrague P, Charriere G, Carriere A, Penicaud L. Plasticicity of adipose tissue: a promising therapeutic avenue in the treatment of cardiovascular and blood diseases? Arch Mal. Coeur Vaiss. 2005;98(9):922-926.

26. Pak J. Autologous adipose tissue-derived stem cells induce persistent bone-like tissue in osteonecrotic femoral heads. Pain Physician. 2012;15(1):75-85.

27. Sakaguchi Y, Sekiya I, Yagishita K, Muneta T. Comparison of human stem cells derived from various mesenchymal tissues: superiority of synovium as a cell source. Arthritis Rheumatol. 2005;52(8):2521-2529.

28. Buckley $C T$, et al. Functional properties of cartilaginous tissues engineered from infrapatellar fat pad-derived mesenchymal stem cells. Journal of Biomechanics. 2010;43(5):920926.

29. Qi GF Y, Yan W. Mesenchymal stem cell-based treatment for cartilage defects in osteoarthritis. Mol Biol Rep. 2012;39(5):5683-5689.

30. Koh YG, Choi YJ. Infrapatellar fat pad-derived mesenchymal stem cell therapy for knee osteoarthritis. Knee. 2012;19(6):902-907.

31. ML, Karli DC, Rettig AC. Efficacy of platelet-rich plasma for chronic tennis elbow: a doubleblind, prospective, multicenter, randomized controlled trial of 230 patients. Am J Sports Med. 2014;42(2):463-471.

32. Centeno C. And Complications Reporting on the Re-Implantation of Cultureexpanded Mesenchymal Stem Cells Using Autologous Platelet Lysate Technique. Curr Stem Cell Res Ther.; 2010.

33. Centeno CJ, et al. Safety and complications reporting on the re-implantation of cultureexpanded mesenchymal stem cells using autologous platelet lysate technique. Curr Stem Cell Res Ther. 2010;6(4):368-378.

34. Centeno C. Increased knee cartilage volume in degenerative joint disease using percutaneously implanted, autologous mesenchymal stem cells.
Pain Physician. 2008;11(3):343-353.

35. Davatchi F. Mesenchymal stem cell therapy for knee osteoarthritis. Preliminary report of four patients. Int J Rheum Dis. 2011;14(2):211-215.

36. Emadedin M. Intra-articular injection of autologous mesenchymal stem cells in six patients with knee osteoarthritis. Arch Iran Med. 2012;15(7):422-428.

37. Lee K. A novel, minimally-invasive technique of cartilage repair in the human knee using arthroscopic microfracture and injections of mesenchymal stem cells and hyaluronic acid-a prospective comparative study on safety and short-term efficacy. Ann Acad Med Singap. 2012;41(11):511-517.

38. Varma HS, Dadarya B, Vidyarthi A. The new avenues in the management of osteo-arthritis of knee-stem cells. J Indian Med Assoc. 2010;108(9):583-585.

39. Wong KL, Lee KBL, Tai BC, Law P, Lee EH, Hui JHP. Injectable cultured bone marrow-derived mesenchymal stem cells in varus knees with cartilage defects undergoing high tibial osteotomy: a prospective, randomized controlled clinical trial with 2 years' follow-up. Arthrosc J Arthrosc Relat Surg Off Publ Arthrosc Assoc N Am Int Arthrosc Assoc. 2013;29(12):2020-2028.

40. Orozco L. Treatment of knee osteoarthritis with autologous mesenchymal stemc: a pilot study. Transplantation. 2013;95(12):1535-1541.

41. Vangsness $C T$, Farr J, Boyd J, Dellaero DT, Mills CR, LeRoux-Williams M. Adult human mesenchymal stem cells delivered via intra-articular injection to the knee following partial medial meniscectomy: a randomized, double-blind, controlled study. J Bone Joint Surg Am. 2014;96(2):90-98.

42. Pak J, Lee JH, Lee SH. A novel biological approach to treat chondromalacia patellae. PLoS One. 2013;8(5):e64569.

43. Pak J. Regeneration of human bones in hip osteonecrosis and human cartilage in knee osteoarthritis with autologous adipose-tissuederived stem cells: a case series. J Med Case Rep. 2011;5:296.

44. Koh Y. Mesenchymal stem cell injections improve symptoms of knee osteoarthritis. Arthroscopy. 2013;29(4):748-755.

45. Kim Y. Clinical outcomes of mesenchymal stem cell injection with arthroscopic treatment in older patients with osteochondral lesions of the 
talus. Am J Sports Med. 2013;41(5):1090-1099.

46. Spasovski $D$, Spasovski V, Baščarević $Z$, et al. Intraarticular injection of autologous adipose-derived mesenchymal stem cells in the treatment of knee osteoarthritis. J Gene Med. 2018;20(1).

47. Saw K. Articular cartilage regeneration with autologous peripheral blood progenitor cells and hyaluronic acid after arthroscopic subchondral drilling: a report of 5 cases with histology. Arthroscopy. 2011;27(4):493-506.

48. Saw K. Articular cartilage regeneration with autologous peripheral blood stem cells versus hyaluronic acid: a randomized controlled trial. Arthroscopy. 2013;29(4):684-694.

49. Turajane T. Combination of intra-articular autologous activated peripheral blood stem cells with growth factor addition/ preservation and hyaluronic acid in conjunction with arthroscopic microdrilling mesenchymal cell stimulation Improves quality of life and regenerates articular cartilage in early osteoarthritic knee disease. J Med Assoc Thai. 2013;96(5):580-588.

50. Vega A, Martín-Ferrero MA, Del Canto F, et al. Treatment of knee osteoarthritis with allogeneic bone marrow mesenchymal stem cells: a randomized controlled trial. Transplantation. 2015;99(8):1681.

51. Lee J. In vivo tracking of mesechymal stem cells using fluorescent nanoparticles in an osteochondral repair model. Mol Ther. 2012;20(7):1434-1442.

52. Moriguchi Y. Repair of meniscal lesions using a scaffold-free tissue-engineered construct derived from allogenic synovial MSCs in a miniature swine model. Biomaterials. 2013;34(9):2185-2193.

53. Patel S. Treatment with platelet-rich plasma is more effective than placebo for knee osteoarthritis: a prospective, doubleblind, randomized trial. Am J Sports Med. 2013;41(2):356-364.

54. Peeters $C$, et al. Safety of intra-articular celltherapy with culture-expanded stem cells in humans: a systematic literature review. Osteoarthritis Cartilage. 2013;21(10):1465-1473.

55. Jo $\mathrm{CH}$, Chai JW, Jeong EC, et al. Intra-articular injection of mesenchymal stem cells for the treatment of osteoarthritis of the knee: a 2-year follow-up study. Am J Sports Med. 2017;45(12):2774-2783.

56. Murphy JM, Dixon K, Beck S, Fabian D, Feldman A,
Barry F. Reduced chondrogenic and adipogenic activity of mesenchymal stem cells from patients with advanced osteoarthritis. Arthritis Rheum. 2002;46(3):704-713. 